\title{
Yield and postharvest quality of winter growing crisphead lettuce as affected by doses of nitrogen and molybdenum
}

\author{
Geraldo M de Resende ${ }^{1}$; Marco Antônio R Alvarenga ${ }^{2}$; Jony E Yuri ${ }^{3}$ Rovilson José de Souza ${ }^{2}$ \\ 'Embrapa Semi-Árido, C. Postal 23, 56302-97 Petrolina-PE; ${ }^{2}$ UFLA, Dep ${ }^{\text {to }}$ Agricultura, C. Postal 37, 37200-000 Lavras-MG; \\ ${ }^{3}$ UNINCOR, Av. Castelo Branco 82, 37410-000 Três Corações-MG; gmilanez@cpatsa.embrapa.br
}

\begin{abstract}
The trial was carried out at Três Pontas, Minas Gerais State, Brazil, from April to July 2003, to evaluate the influence of nitrogen and molybdenum rates on productive characteristics and postharvest quality of crisphead lettuce (Lactuca sativa L.). A randomized complete block design with three replications was used. Treatments were a factorial combination of four nitrogen rates $(0.0 ; 60.0 ; 120.0$ and $\left.180.0 \mathrm{~kg} \mathrm{ha}^{-1}\right)$ applied in additional the dose commonly used by growers $\left(60 \mathrm{~kg} \mathrm{ha}^{-1}\right.$ of $\left.\mathrm{N}\right)$ and five foliar molybdenum rates $(0.0$; $35.1 ; 70.2 ; 105.3$ and $\left.140.4 \mathrm{~g} \mathrm{ha}^{-1}\right)$. The total and commercial fresh weight and head circumference showed significant effects for doses of nitrogen and of molybdenum, as well as for their interaction. No significant effects of the treatments for stem length were observed. There was a linear effect of $\mathrm{N}$ and Mo doses for postharvest conservation at 28 days, and the rate of $150.0 \mathrm{~kg} \mathrm{ha}^{-1}$ of $\mathrm{N}$ showed the best conservation at 35 days after the harvest. The percentage of dry matter showed quadratic effects, and the doses of $95.9 \mathrm{~kg} \mathrm{ha}^{-1}$ of $\mathrm{N}$ and $75.3 \mathrm{~kg} \mathrm{ha}^{-1}$ of Mo showed the highest return.
\end{abstract}

Keywords: Lactuca sativa L., fresh weight, nutrition, storage.

\section{RESUMO}

Rendimento e qualidade pós-colheita de alface americana em função de doses de nitrogênio e molibdênio

O trabalho foi conduzido no município de Três Pontas, Sul de Minas Gerais, de abril a julho de 2003, com o objetivo de avaliar a influência de doses de nitrogênio e molibdênio nas características produtivas e qualidade pós-colheita da alface tipo americana (Lactuca sativa L.). Utilizou-se o delineamento de blocos ao acaso em arranjo fatorial $4 \times 5$, compreendendo quatro doses de nitrogênio em cobertura adicionais à dose aplicada pelo produtor de $60 \mathrm{~kg} / \mathrm{ha}$ de $\mathrm{N}(0 ; 60$; 120 e $\left.180 \mathrm{~kg} \mathrm{ha}^{-1}\right)$ e cinco doses de molibdênio via foliar $(0,0 ; 35,1$; 70,$2 ; 105,3$ e 140,4 $\mathrm{g} \mathrm{ha}^{-1}$ ) com três repetições. As massas fresca total e comercial e a circunferência da cabeça evidenciaram efeitos significativos para doses de nitrogênio em cobertura e de molibdênio, assim como para sua interação. Não se observou efeito significativo dos tratamentos para comprimento do caule. Houve uma resposta linear para doses de $\mathrm{N}$ e Mo para conservação pós-colheita aos 28 dias, sendo que a dose de $150,0 \mathrm{~kg} \mathrm{ha}^{-1}$ de $\mathrm{N}$ em cobertura promoveu a melhor conservação aos 35 dias após a colheita. A dose de $95,9 \mathrm{~kg}$ $\mathrm{ha}^{-1}$ de $\mathrm{N}$ em cobertura e a dose $75,3 \mathrm{~kg} \mathrm{ha}^{-1}$ de Mo propiciariam o maior retorno em termos de percentagem de massa seca.

Palavras-chave: Lactuca sativa L., massa fresca, nutrição, armazenamento.

(Recebido para publicação em 7 de outubro de 2009; aceito em 18 de agosto de 2010) (Received on October 7, 2009; accepted on August 18, 2010)

$\mathrm{C}$ Trisphead lettuce has grown in importance in Brazil. This type of lettuce is planted to attend the needs of the fast food market, and currently, there is an increase in the demand for this vegetable also for salads (Resende et al., 2007).

As lettuce is a crop composed mostly of leaves, it responds well to nitrogen fertilization. A deficiency of nitrogen retards the growth of the plant and induces the absence or malformation of the head, the older leaves turn yellow and come off with ease. However, when applied in excess, in side dressing in the last third of the cycle, the cultivars that form a head show less firmness, which could be detrimental in marketing (Garcia et al., 1982). Broadley et al. (2000) reported a negative relation between plants under normal conditions of available nitrogen and deficient plants, where there was a reduction in fresh weight of the leaves, under limitations of this nutrient.

Molybdenum is a constituent of at least five enzymes and its most important function in plants is related to nitrogen metabolism (Chairidchai, 2000), linked to the action or enzymatic activation, mainly of the enzymes nitrogenase and nitrate reductase (Dechen et al., 1991). These enzymes together with sulfite oxidase are found in plants (Gupta \& Lipsett, 1981).

The application of nitrogen on the soil together with the application of molybdenum on the leaves, could be a way to improve the fertilization of this crop, with the more rational use of nitrogen, and for a greater activity of the enzyme nitrate reductase by means of molybdenum fertilization.

The objective of this work was to evaluate the effects of nitrogen rates as side dressing and molybdenum by foliar fertilization, on production characteristics, post-harvest quality, and the performance of crisphead lettuce grown in winter.

\section{MATERIAL AND METHODS}

The experiment was conducted from April to July of 2003, in Tres Pontas, south of Minas Gerais State $\left(21^{\circ} 22^{\prime} 00^{\prime \prime} \mathrm{S}\right.$ and $45^{\circ} 30^{\prime} 45^{\prime \prime} \mathrm{W}$, altitude of $870 \mathrm{~m}$ ), using a soil classified as dystroferric red latosol with clayey texture (Santos et al., 2006). An analysis of the soil in which 
the experiment was carried out showed the following chemical characteristics: $\mathrm{K}=73.0 \mathrm{mg} \mathrm{dm}^{-3}, \mathrm{P}=72.7 \mathrm{mg} \mathrm{dm}^{-3}$, $\mathrm{Ca}=4.5 \mathrm{cmol} \mathrm{dm}^{-3}, \mathrm{Mg}=0.7 \mathrm{cmol}_{\mathrm{c}}$ $\mathrm{dm}^{-3}, \mathrm{Al}=0.0 \mathrm{cmol}_{\mathrm{c}} \mathrm{dm}^{-3}, \mathrm{H}+\mathrm{Al}=2.3$ $\mathrm{cmol}_{\mathrm{c}} \mathrm{dm}^{-3}$, $\mathrm{pH}$ in $\mathrm{H}_{2} \mathrm{O}=6.3$ and O.M.= $2.9 \mathrm{dag} \mathrm{kg}^{-1}$.

The experiments were carried out using a randomized block design with a 4 x 5 factorial scheme. We studied four rates of nitrogen as side dressing $\left(0,60,120\right.$ and $\left.180 \mathrm{~kg} \mathrm{ha}^{-1}\right)$, in addition to the level applied by the grower ( 60 $\mathrm{kg} \mathrm{ha}^{-1}$ nitrogen), and five rates of foliar molybdenum $(0.0,35.1,70.2,105.3$ and $140.4 \mathrm{~g} \mathrm{ha}^{-1}$ ), with three repetitions, giving a total of 20 treatments. Urea was used as nitrogen fertilizer and sodium molybdate was the source of molybdenum. Urea was applied as side dressing at 10, 20 and 30 days after transplanting at $40 \%, 30 \%$ and $30 \%$, respectively, of the rate evaluated. The rates of urea per plot per plant were applied as a $10-\mathrm{mL}$ solution, previously diluted in pure water, to the side of each plant. Sodium molybdate was applied at 21 days after transplanting using a manual backpack sprayer with a 4-L capacity at maximal pressure, producing $300 \mathrm{~L} \mathrm{ha}^{-1}$ of spray.

The preparation of the soil consisted of plowing, harrowing and raising the seedbeds to $0.20 \mathrm{~m}$ in height. The seedlings were prepared in 288cell trays, with each cell filled with commercial substrate (Plantmax). Transplanting was at 25 days after sowing, utilizing the cultivar Raider.

The experimental plots consisted of seedbeds with four rows $2.1 \mathrm{~m}$ long, spaced $0.30 \mathrm{~m}$ apart with plants being $0.35 \mathrm{~m}$ apart. The central rows formed the area to be studied, where two plants at each end were excluded. A protective structure was installed in the whole area; it consisted of high tunnels 2.0 $\mathrm{m}$ high, covering two seedbeds per tunnel, and was made of galvanized iron tubes, covered with a low-density, transparent plastic sheet, which was 100 $\mu \mathrm{m}$ thick and with added anti-UV. The seedbeds were covered with a black plastic sheet (mulching), $4 \mathrm{~m}$ wide and $35 \mu \mathrm{m}$ thick.

The basic fertilization at planting carried out by the grower consisted of
$1500 \mathrm{~kg} \mathrm{ha}^{-1}$ formulation 02-16-08 and $1000 \mathrm{~kg} \mathrm{ha}^{-1}$ simple superphosphate. After incorporating the fertilizers into the soil, two lines of drip piping were installed in each seedbed, with nozzles spaced every $30 \mathrm{~cm}$ and with a flow rate of $1.5 \mathrm{~L} \mathrm{~h}^{-1}$. The side dressing were carried out by means of daily fertigations, totaling $30 \mathrm{~kg} \mathrm{ha}^{-1} \mathrm{~N}$ and 60 $\mathrm{kg} \mathrm{ha}^{-1} \mathrm{~K}$, utilizing urea and potassium chloride as sources.

The crop was kept clean by manual weeding, when necessary, and the pest control used was the standard method of the grower, with weekly spraying with pesticides containing copper oxychloride, iprodione, procymidone and pyrethroids.

Transplanting of the seedling was done on May 13, 2003. Harvest was 36 days after transplanting, when the plants appeared to be completely developed, at which time the following parameters were assessed: total fresh weight and commercial fresh weight (head) ( $\mathrm{g}$ plant $\left.^{-1}\right)$; circumference and length of the stem of the commercial part in $\mathrm{cm}$ (head), percentage of dry weight of the commercial part (sample of $\pm 300 \mathrm{~g}$ ). The samples were washed in running water and in distilled water and dried in convection oven, at $65-70^{\circ} \mathrm{C}$, until reaching constant weight. The data of percentage of dry weight were transformed to arcsine $\sqrt{P / 100}$. Postharvest conservation was determined with a sample of two commercial heads of lettuce, evaluated at 7, 14, 21,28 and 35 days, in a cold room at $5 \pm 2{ }^{\circ} \mathrm{C}$ and relative humidity of $90 \pm 2 \%$, according to grades (grade 1: commercial heads extremely deteriorated; grade 2: commercial heads deteriorated; grade 3: commercial heads moderately deteriorated; grade 4: commercial heads slightly deteriorated and grade 5: commercial heads without deterioration), where three evaluators were utilized to determine the mean grade.

The collected data were submitted to analysis of variance and regression based on the polynomial model at the $5 \%$ level of significance.

\section{RESULTS AND DISCUSSION}

The total fresh weight of the aerial part showed significant effects for rates of nitrogen and molybdenum, as well as for the interaction between these nutrients. Except for the rate of $35.1 \mathrm{~g} \mathrm{ha}^{-1}$ molybdenum which fit a linear model, the other rates were fitted to quadratic models with points of maximal productivity of total fresh weight varying with the rate of nitrogen applied (Figure 1).

In the absence of fertilization with molybdenum, the rate of nitrogen of $91.8 \mathrm{~kg} \mathrm{ha}^{-1}$ as dressing gave the highest return in terms total fresh weight of lettuce. When rates of 70.2, 105.2 and $140.4 \mathrm{~g} \mathrm{ha}^{-1}$ molybdenum were applied, respective rates of 107.1, 111.1 and $99.5 \mathrm{~kg} \mathrm{ha}^{-1}$ nitrogen as dressing provided the greatest weights. Taking into consideration that the grower utilized 30.0 and $30.0 \mathrm{~kg} \mathrm{ha}^{-1}$ $\mathrm{N}$, respectively, at planting and as daily dressings, totaling $60.0 \mathrm{~kg} \mathrm{ha}^{-1}$, during the crop cycle, it can be inferred that these rates, based on the results obtained, are insufficient for achieving the maximal productivity of total fresh weight per plant, which in the absence of fertilization with molybdenum was achieved completely with $151.8 \mathrm{~kg} \mathrm{ha}^{-1}$ nitrogen, that is, $153.0 \%$ higher than the rate utilized by the grower. Alvarenga et al. (2000) transplanted the same cultivar in May and observed effects of the interaction nitrogen $\mathrm{x}$ calcium, pointing out that better results were obtained in the absence of calcium with $1,011.0 \mathrm{~g}$ plant $^{-1}$, declining down to 809.1 g plant $^{-1}$, where these weights are within variation range found in the present work. These results are a little above those obtained by Thompson \& Doerge (1996a), who found for butter lettuce, maximal productivity when utilizing $165.0 \mathrm{~kg}$ $\mathrm{ha}^{-1}$ nitrogen, and lower than those obtained by McPharlin et al. (1995) in Australia, who determined a maximal production with rates of 288.0 and 344 $\mathrm{kg} \mathrm{ha}^{-1} \mathrm{~N}$, in two years of study, utilizing the cultivar Salinas. Positive results for productivity with the sole application of molybdenum in winter cultivation of the same cultivar were reported by Resende et al. (2008). The difference in these results is probably due to the cultivar utilized, edaphoclimatic conditions 


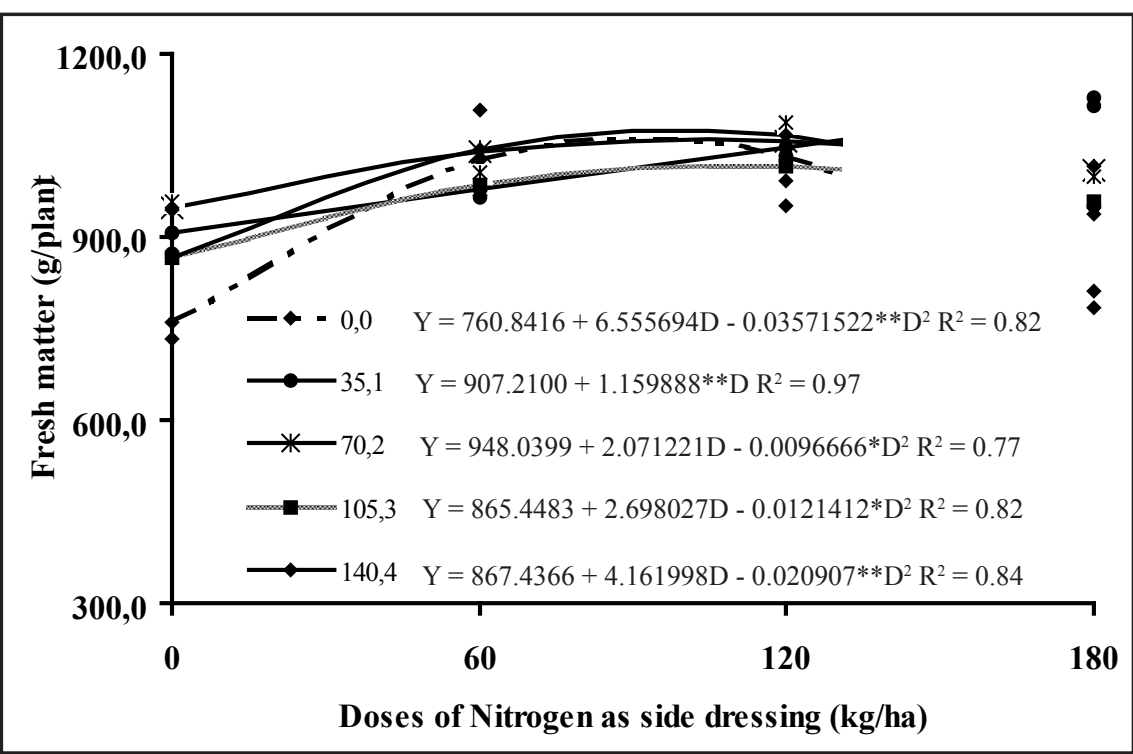

Figure 1. Total fresh weight of crisphead lettuce submitted to $0.0 ; 35.1 ; 70.2$ and $105.3 \mathrm{~g} \mathrm{ha}^{-1}$ molydenum levels in response to nitrogen levels (massa fresca total da alface tipo americana nas doses 0,$0 ; 35,1 ; 70,2$ e 105,3 $\mathrm{g} \mathrm{ha}^{-1}$ de molibdênio em função de doses de nitrogênio). Três Pontas, Embrapa Semi-Árido, 2003.

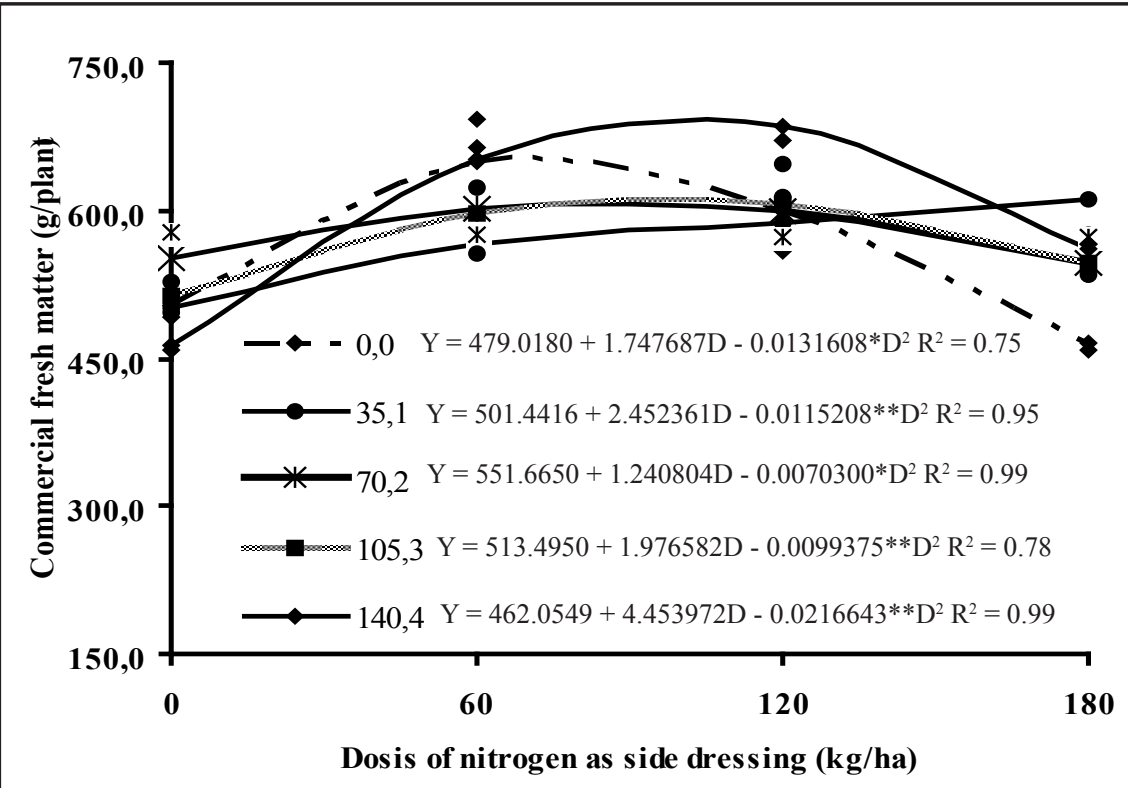

Figure 2. Commercial fresh mass of crisphead lettuce submitted to $0.0 ; 35.1 ; 70.2$ and 105.3 $\mathrm{g} \mathrm{ha}^{-1}$ molydenum levels in response to nitrogen levels (massa fresca comercial da alface tipo americana nas doses 0,$0 ; 35,1 ; 70,2$ e 105,3 $\mathrm{g} \mathrm{ha}^{-1}$ de molibdênio em função de doses de nitrogênio). Três Pontas, Embrapa Semi-Árido, 2003.

and irrigation management, important factors in the productivity of the crop.

Similar results were obtained for commercial fresh weight where, in elucidating the interaction of molybdenum rates within the nitrogen rates studied, quadratic models were established with points of maximal production of fresh weight with or without the application of molybdenum rates of $106.4,88.2,99.4$ and $102.8 \mathrm{~kg}$ $\mathrm{ha}^{-1}$ nitrogen as dressing were needed to provide the highest returns. Adding to the $60.0 \mathrm{~kg} \mathrm{ha}^{-1}$ nitrogen employed by the grower, it is seen that rates varying from 148.2 to $166.4 \mathrm{~kg} \mathrm{ha}^{-1}$ resulted in the highest productions with regard to commercial fresh weight, fluctuating with the application of molybdenum.

In the absence of the molybdenum fertilization a yield of $509.5 \mathrm{~g} \mathrm{plant}^{-1}$ (head) was obtained. When the highest rates of nitrogen and molybdenum were employed the yield of heads was of 690.9 g plant $^{-1}$. These results are much better than those found by Bueno (1998), with the highest rate of nitrogen used (105.6 $\left.\mathrm{kg} \mathrm{ha}^{-1}\right)$, producing the equivalent of $461.1 \mathrm{~g} \mathrm{plant}^{-1}$ as also the results obtained by Alvarenga et al. (2000), who did not find significant differences between rates of 120 and 240 $\mathrm{kg} \mathrm{ha}^{-1} \mathrm{~N}$, but did observe a maximal fresh weight at $609.2 \mathrm{~g} \mathrm{plant}^{-1}$. The importance of nitrogen fertilization was reported by Broadley et al. (2000) who noted a negative relation between plants under normal conditions of available nitrogen and deficient plants, where a reduction in leaf weight occurred under conditions limiting this nutrient. The results obtained, however, are still a level lower than the recommended rates of nitrogen utilized in the United States, which according to Thompson \& Doerge (1996a, b), vary from 224.0 to 370.0 $\mathrm{kg} \mathrm{ha}^{-1}$, probably due to the cultivar, type of soil, climatic conditions and management of the crop, as mentioned previously.

The circumference of the commercial part (head) is one of the main characteristics for crisphead lettuce, considering the preference of the consumer for the acquisition of the product (Bueno, 1998). Like the preceding characteristics, for the circumference of the commercial head, the factors studied showed significant effects for rates of nitrogen and molybdenum, and for the interaction of these nutrients (Figure 3). They were fitted to quadratic models with points of maximal circumference in the absence of molybdenum as well as with its application. In the absence of molybdenum fertilization, a rate of 98.3 


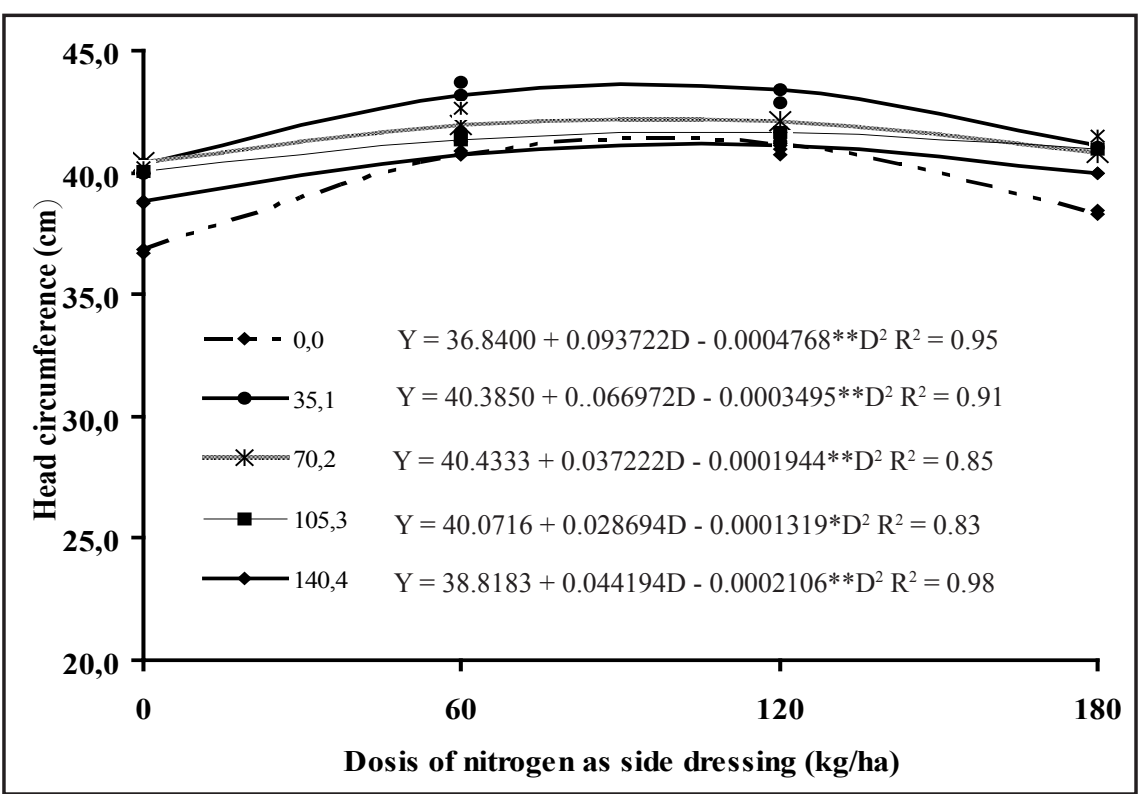

Figure 3. Head circumference of crisphead lettuce submitted to $0.0 ; 35.1 ; 70.2$ and 105.3 $\mathrm{g} \mathrm{ha}^{-1}$ molydenum levels in response to nitrogen levels (circunferência da cabeça da alface tipo americana nas doses 0,$0 ; 35,1 ; 70,2$ e 105,3 $\mathrm{g} \mathrm{ha}^{-1}$ de molibdênio em função de doses de nitrogênio). Três Pontas, Embrapa Semi-Árido, 2003.

Table 1. Dry matter (\%) and postharvest conservation at 28 and 35 days in response to nitrogen and molybdenum levels (massa seca (\%) e conservação pós-colheita aos 28 e 35 dias em função das doses de nitrogênio e molibdênio). Três Pontas. 2003.

\begin{tabular}{|c|c|}
\hline Variables & Regression equations \\
\hline \multirow{2}{*}{ Dry mass ${ }^{1}$} & $(\mathrm{~N}) \mathrm{Y}=10.2236+0.0110626 \mathrm{X}-0.0000554 * \mathrm{X}^{2} \quad \mathrm{R}^{2}=0.99$ \\
\hline & $(\mathrm{Mo}) \mathrm{Y}=10.2222+0.012291 \mathrm{X}-0.0000816 * * \mathrm{X}^{2} \mathrm{R}^{2}=0.96$ \\
\hline \multirow{2}{*}{$\begin{array}{l}\text { Post-harvest con- } \\
\text { servation ( } 28 \text { days) }\end{array}$} & (N) $\mathrm{Y}=3.5000+0.003611 * * \mathrm{X} \quad \mathrm{R}^{2}=0.87$ \\
\hline & (Mo) $\mathrm{Y}=3.4750+0.004985^{* *} \mathrm{X} \quad \mathrm{R}^{2}=0.67$ \\
\hline $\begin{array}{l}\text { Post-harvest con- } \\
\text { servation ( } 35 \text { days) }\end{array}$ & (N) $\mathrm{Y}=32.0500+0.009722 \mathrm{X}-0.0000324 * * \mathrm{X}^{2} \quad \mathrm{R}^{2}=0.98$ \\
\hline
\end{tabular}

${ }^{1}$ Data transformed in arcsine $\sqrt{P / 100} ; * *$ significant at $1 \%$ level in the $\mathrm{F}$ test (dados transformados em arco-seno $\sqrt{P / 100}$; **Significativo ao nível de $1 \%$ pelo teste de F).

$\mathrm{kg} \mathrm{ha}^{-1} \mathrm{~N}$ as dressing produced a larger circumference of the commercial head, reaching $41.4 \mathrm{~cm}$.

For the rates of $35.1,70.2,105.3$ and $140.4 \mathrm{~g} \mathrm{ha}^{-1}$ molybdenum (Figure $3)$, derivation of the regression equations gave the nitrogen rates of 95.8, 95.7, 108.8 and $104.9 \mathrm{~kg} \mathrm{ha}^{-1}$ as those providing the highest returns in head circumference, which fluctuated between 41.1 and $43.69 \mathrm{~cm}$. These results are close to those obtained by Bueno (1998), who found a maximal circumference of 44.98 with an increase in nitrogen rate. These results are similar to those reported by Alves (1996), who observed a significant increase in the circumference of commercial heads up to $9.0 \mathrm{~cm}$ being acceptable and unacceptable or less recommended for processing above this level. In this context, there was variation between 2.02 and $2.14 \mathrm{~cm}$ in the rates of nitrogen and for rates of molybdenum, between 2.01 and $2.13 \mathrm{~cm}$, which was within the range adequate for the crop. It should be noted that there is a tendency for crisphead lettuce under conditions of winter cultivation to have shorter stems, compared to summer cultivation, probably due to its better adaptation to cultivation under conditions of amenable temperature. Similar results for the rates of molybdenum were found by Yuri et al. (2004a), who demonstrated significant effects for stem length. However, the results do not concur with those obtained by Bueno (1998), who found a linear increase in stem length with increase of nitrogen rates.

Analysis of variance revealed significant differences for the percentage of dry weight, for rates of both nitrogen and molybdenum, in an independent way (Table 1). Quadratic models were determined for the two nutrients, in which through the derivate of the equations, it was estimated that a rate of $95.9 \mathrm{~kg} \mathrm{ha}^{-1} \mathrm{~N}$ as dressing in addition to the rate applied by the grower of $60.0 \mathrm{~kg} \mathrm{ha}^{-1}$ provided a greater return in terms of dry weight of the plant (Table 1). Similar results are observed in the works of Alves (1996) and Fontes et al. (1997), who obtained a positive effect for dry weight of the lettuce cultivars Regina 440 and Brasil 202, in response to the addition of nitrogen. However, Alvarenga et al. (2000) did not detect significant differences in the production of dry weight with fertilizations with nitrogen and calcium. In peppers, Silva (1998) and Nannetti (2001) reported a favorable effect of $\mathrm{N}$ in the production of dry weight of the fruits.

With regard to the rates of molybdenum, $75.3 \mathrm{~g} / \mathrm{ha}$ provided the greatest response in terms of dry weight of the commercial part of crisphead lettuce (Table 1). Also in cauliflower, Novelino \& Chaves (1987) found a tendency of an increase in the accumulation of dry weight in the plants, with foliar application of 24 and $48 \mathrm{~g}$ ha $^{-1}$ Mo. 
Post-harvest conservation was evaluated in a cold room at $7,14,21$, 28 and 35 days after harvest. At 7 and 14 days, the commercial heads appeared perfectly conserved. At 21 days after harvest, the heads that received nitrogen showed grades varying between 4.8 and 4.9 and those that received molybdenum showed grades of 4.8 to 5.0 , noting that these indices represent heads slightly deteriorated or without deterioration. Evaluation at 28 days after harvest showed significant effects for the rates of nitrogen and molybdenum studied, where they were fitted to linear models with the increase in rates of nitrogen and molybdenum (Table 1).

With regard to post-harvest conservation at 35 days after harvest (Table 1), significant effects were found only for rates of nitrogen which were fitted to a quadratic model with the point of maximal conservation at a nitrogen rate of $150.0 \mathrm{~kg} \mathrm{ha}^{-1}$ as dressing in addition to the level of 60.0 $\mathrm{kg} \mathrm{ha}^{-1}$ utilized by the grower. This characteristic is of great importance in crisphead lettuce since the final product is processed and stored in cold rooms for later distribution. Therefore, a greater conservation of the product after its harvest is desirable and of considerable relevance.

As production is basically determined by the leaves, among all the nutrients absorbed by lettuce, nitrogen is the one that provides the greatest increase in productivity and in weight of the plant. A deficiency of nitrogen retards the growth of the plant and induces the absence or malformation of the head, where the older leaves become totally yellowish and come off with ease (Garcia et al., 1982). A good vegetative development of crisphead lettuce, culminating in an optimal formation of the head and compactness, probably explains the better post-harvest conservation caused by nitrogen fertilization. In the literature, there are reports of a small effect on the loss of weight by the addition of nitrogen (Poulsen et al., 1994) and of better post-harvest conservation with fertilization with other nutrients such as silicon and boron (Resende et al., 2005; Yuri et al., 2004b).

There was an interaction between the rates of nitrogen as side dressing and of foliar molybdenum, which positively influenced the total commercial fresh weight, head circumference, dry weight and post-harvest conservation, where a significant effect was observed on the length of the stem of crisphead lettuce. In the absence of fertilization with molybdenum, a rate of $134.8 \mathrm{~kg}$ $\mathrm{ha}^{-1}$ nitrogen as dressing provided a maximal productivity of commercial fresh weight, and with the application of $35.1,70.2,105.3$ and $140.4 \mathrm{~kg} \mathrm{ha}^{-1}$ molybdenum (added to the $60.0 \mathrm{~kg}$ $\mathrm{ha}^{-1}$ nitrogen used by the grower), rates varying from 148.2 to $166.4 \mathrm{~kg} \mathrm{ha}^{-1}$ gave the highest yields.

\section{REFERENCES}

ALVARENGA MAR; SILVA EC; SOUZA RJ; CARVALHO JG. 2000. Efeito de doses de nitrogênio aplicadas no solo e níveis de cálcio aplicados via foliar sobre o teor e o acúmulo de micronutrientes em alface americana. Ciência e Agrotecnologia 24: 905-916.

ALVES DRBA. 1996. Efeito de adubação nitrogenada via fertirrigação e aplicação de forma convencional na produção de alface (Lactuca sativa L.) em estufa. Botucatu: UNESP, 76p. (Tese mestrado).

BROADLEY MR; ESCOBAR - GUTIERREZ AJ; BURNS AJ; BURNS IG. 2000. What are the effects of nitrogen deficiency on growth components of lettuce? New Phytologist 147: 519-526.

BUENO CR. 1998. Efeito da adubação nitrogenada em cobertura via fertirrigação por gotejamento para a cultura da alface tipo americana em ambiente protegido. Lavras: UFLA. 54p. (Tese mestrado)

CHAIRIDCHAI P. 2000. The relationships between nitrate and molybdenum contents in pineapple grown on an inceptisol soil. Acta Horticulturae 529: 211-216.

DECHEN AR; HAAG HP; CARMELLO QAC. 1991. Funções de micronutrientes nas plantas. In: FERREIRA ME; CRUZ MCP. (eds.). Micronutrientes na agricultura. Piracicaba: POTAFOS/CNPq. p. 65-78.

FONTES PCR; PEREIRA PRG; CONDE RM. 1997. Critical chlorophyll, total nitrogen, and nitrate-nitrogen in leaves associated to maximum lettuce yield. Journal of Plant Nutrition 20: 1061-1068.

GARCIA LCL; HAAG HP; DIEHL NETO V. Nutrição mineral de hortaliças XXXVIII. Deficiências de macronutrientes em alface (Lactuca sativa L.), cv. Brasil 48 e Clause's Aurélia. 1982. Anais da Escola Superior de Agricultura Luiz de Queiroz 39: 349-372.

GUPTA UC; LIPSETT J. 1981. Molybdenum in soils, plants, and animals. Advances in Agronomy 34: 73-115.

McPHARLIN IR; AYLMORE PM; JEFFERY RC.
1995. Nitrogen requeriments of lettuce under sprinkler irrigation and trickle fertigation on a spearwood sand. Journal of Plant Nutrition 18: 219-241.

NANNETTI DC. 2001. Nitrogênio e potássio aplicados via fertirrigação na produção, nutrição e pós-colheita do pimentão. Lavras: UFLA. 184p. (Tese mestrado).

NOVELINO JO; CHAVES JF. 1987. Aplicação de molibdênio e boro em couve-flor. Horticultura Brasileira 5: 68.

POULSEN N; SORENSEN JN; JOHANSEN AS. 1994. Influence on growth conditions on the value of crisphead lettuce. 2. Weight losses during storage as affected by nitrogen, plant age and cooling system. Plant Foods for Humam Nutrition 46: 13-18.

RESENDE GM; YURI JE; SOUZA RJ. 2007. Épocas de plantio e doses de silício no rendimento de alface tipo americana. Horticultura Brasileira 25: 455-459.

RESENDE GM; YURI JE; MOTA JH; RODRIGUES JÚNIOR JC; SOUZA RJ; CARVALHO JG. 2005. Produção de alface americana em função de doses e épocas de aplicação de Supa Potássio®. Horticultura Brasileira 23: 174-178.

RESENDE GM; YURI JE; MOTA JH; SOUZA RJ. 2008. Resposta de alface tipo americana a doses e épocas de aplicação de molibdênio em cultivo de inverno. Ciência e Agrotecnologia 32: 143-148.

RESENDE GM; YURI JE; MOTA JH; SOUZA RJ; FREITAS SAC; RODRIGUES JÚNIOR JC. 2003. Efeitos de tipos de bandejas e idade de transplantio de mudas sobre o desenvolvimento e produtividade de alface americana. Horticultura Brasileira 21: 562567.

SANTOS HG; JACOMINE PKT; ANJOS LHC; OLIVEIRA VA; OLIVEIRA JB; COELHO MR; LUMBRERAS JF; CUNHA TJF. (eds.). 2006. Sistema brasileiro de classificação de solos. 2. ed. Rio de Janeiro: Embrapa Solos, 2006. 306p.

SILVA MAG. 1998. Efeito do nitrogênio e potássio na produção e nutrição do pimentão em ambiente protegido. Piracicaba: ESALQ. 86p. (Tese doutorado).

THOMPSON TL; DOERGE TA. 1996a. Nitrogen and water interactions in subsurface trickleirrigated leaf lettuce: I. Plant response. Soil Science Society of American Journal 60: 163-168.

THOMPSON TL; DOERGE TA. 1996b. Nitrogen and water interactions in subsurface trickleirrigated leaf lettuce: II. Agronomic, economic, and environmental outcomes. Soil Science Society of American Journal 60: 168-173.

YURI JE; RESENDE GM; MOTA JH; GONÇALVES LD; SOUZA RJ. 2004a. Doses e épocas de aplicação de molibdênio na produção e qualidade de alface. Horticultura Brasileira 22: 589-592.

YURI JE; RESENDE GM; MOTA JH; RODRIGUES JÚNIOR JC; SOUZA RJ.; CARVALHO JG. 2004b. Comportamento de alface americana em função do uso de doses e épocas de aplicação de boro em cultivo de inverno. Horticultura Brasileira 22: 593-596. 